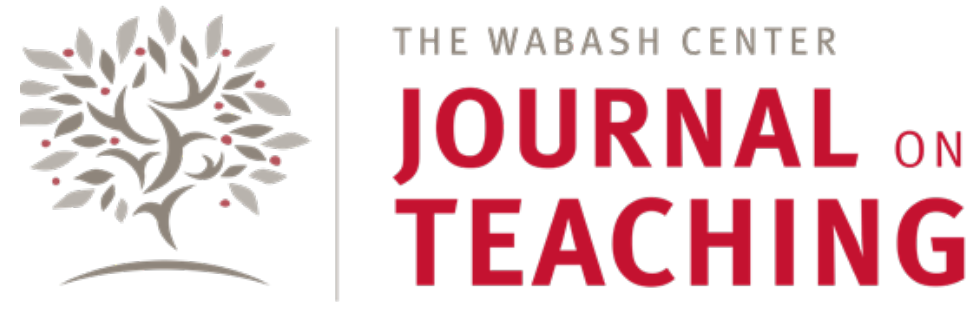

ARTICLE

\title{
The Past, Present, and Religious Studies Future of Civic Engagement in American Higher Education
}

\author{
Sara Ronis \\ St. Mary's University \\ Travis Proctor \\ Wittenberg University
}

\begin{abstract}
In this article, we argue that civic engagement is fundamental to the stated work of the university, the humanities, and the project of religious studies. We trace the historical connections between civic engagement and higher education in the American context to the present period, highlighting a consistency of focus on civic engagement across diverse university contexts even as educational priorities and instantiations shift. We then explore the particular role of civic engagement in religious studies pedagogy. We contend that being explicit about integrating civic engagement in the late antique religion classroom, rather than dismissing it as either difficult to incorporate or as tangential to our subject areas, actually enhances our students' ability to understand complex concepts in late antique religion and underscores for them how relevant the study of late ancient religion is to students' lives today. We ultimately offer three ways that instructors in religious studies can incorporate civic engagement into their classes: cultivating naming practices, focusing pedagogical exercises on honing students' civic engagement skills, and, where practicable, engaging in community-based learning.
\end{abstract}

\section{KEYWORDS}

U.S. history of community-based learning, religious studies pedagogy, courses on religion in late antiquity, naming practices, community-based learning, civic engagement, mission-statements

According to the Babylonian Talmud, the fourth-century CE sage Rav Hamnuna used to say: "Jerusalem was only destroyed because they neglected the school-age children, as it says, 'Pour it [God's wrath] out on the children in the street' (Jeremiah 6:11, NRSV). What is the reason [God's wrath] poured out? Because [the children] are outside [and not in school]" (b. Shabbat 119b). The rabbis of the Babylonian Talmud recognized the importance of education to the continuation of the polity. The rabbis describe its importance not in metaphysical or aspirational terms; according to Rav Hamnuna's reading of the verse from Jeremiah, Jerusalem was literally destroyed because formal education ceased. The connection between education and the physical and intellectual well-being of the community as a whole is an ancient insight, but it is one with important afterlives. 
The connection between education and the polity is yet again a subject of discussion as they relate to the college classroom. Unlike in the Babylonian Talmud, this connection is no longer framed as biblical interpretation, but rather as civic engagement. The term "civic engagement" may be popular with university administrators, but its parameters, relevance, and applicability in the religious studies classroom are shifting and subject to debate. In this article, we will argue that civic engagement is fundamental to the stated work of the university, the humanities, and the project of religious studies, and that being explicit in integrating civic engagement in the late antique religion classroom, rather than dismissing it as overly difficult or tangential to our subject, is crucial for our our students' ability to understand complex concepts in late antique religion as well as their relevance to our students' own lives today.

We first trace the historical connections between civic engagement and higher education in the American context to the present period, highlighting a consistency of focus on civic engagement across diverse university contexts even as educational priorities and instantiations shift. Civic engagement has been defined as part of broader political movements and notions of the polity, and it is crucial to the educational project; it also shifting, malleable, and deeply political. We then explore the particular role of civic engagement in religious studies pedagogy. We contend that being explicit about integrating civic engagement in the late antique religion classroom, rather than dismissing it as either difficult to incorporate or as tangential to our subject areas, actually enhances our students' ability to understand complex concepts in late antique religion and underscores for them how relevant the study of late ancient religion is to students' lives today. We ultimately offer three ways that instructors in religious studies can incorporate civic engagement into their classes: cultivating naming practices, focusing pedagogical exercises on honing students' civic engagement skills, and, where practicable, engaging in community-based learning.

\section{Civic Engagement: One Aim, But Many Definitions Across History}

Civic engagement and higher education have been intertwined from the very beginning of colonial settlement in America. The earliest colonial colleges were founded with the express purpose of training clergy and the future leaders of first a colonial government, and then the fledgling American republic. ${ }^{1}$ Both Thomas Jefferson and Benjamin Franklin championed education as essential for training a new generation of (white, male, upper-class, Christian, [see discussion below]) leaders to carry on democratic ideals (Woolard 2017, 45; Jacoby 2009, 10; Musil 2015, 240). These colonial and revolutionary leaders understood education to provide these civic services through the transmission of culture and training in habits of civic politesse. In imitation of British educational systems of the time, the curricula of colonial and post-revolutionary colleges focused on classical languages, literature, and history alongside training in logic, rhetoric, ethics, theology, and philosophy (Musil 2015, 240; Smith, Mayer, and Fritschler 2008, 25). It was believed that familiarity with particular cultural and philosophical traditions would mold the next generation of leaders into good stewards of the new republic. The belief that familiarity with particular cultural and philosophical traditions would shape the next generation of leaders into good stewards of the new republic was eventually adopted into law. Article 3 of the Congress Land Ordinance of 1787, which regulated schooling in what were then the Northwest Territories, identified "religion, morality, and knowledge" as "necessary to good government and the happiness of [hu]mankind" (Musil 2015, 241). Colleges also promoted their civic formation through the formation of particular scholastic habits:

The organizing idea of the old system was that the students should study a fixed set of courses, memorize and recite their lessons, study ancient languages, and observe discipline and rigid rules of dress and decorum (teachers often lived in the student quarters and acted as proctors). Students would thus acquire the strength of character and mental toughness needed to thrive in their chosen profession. Students would, as a byproduct or sometimes as a central goal of their education, become good Christians and good citizens. (Smith, Mayer, and Fritschler 2008, 30)

In the mid-late nineteenth century, political and social movements began to broaden the scope of higher education in America beyond the upper-class, while continuing to insist on the link between higher education and proper civic engagement. The Morrill Act of 1862 inaugurated land grant colleges, while Gilded Age philanthropy led to the opening of many private universities (Jacoby 2009 , 10-11). The trustees of the Ohio Agricultural and Mechanical College (later Ohio State University) asserted that the school aimed to train students "fitted by education and attainments for the greater usefulness and higher duties of citizenship" (Boyte and Kari 2000 , 47; Hartley 2011, 28). In similar fashion, the "Wisconsin Idea," inaugurated in 1903 by the University of Wisconsin President Charles Van Hise and the state Governor, Robert La Follette, conceived of higher education as working hand-in-hand with the state legislature for the promotion of general societal flourishing; Van Hise declared in a 1905 address that he would "never be content until the beneficent influence of the University reaches every family of the state" (University of Wisconsin 2020). Many educational leaders in the early twentieth century drew upon the philosophy of the reformer John Dewey, who insisted that American education should have as its

1 Yale's 1701 charter, for example, described its mission as training "youth" such that they may be "fitted for public employment, both in Church and civil state" (Yale University 2020). For more on the history and evolution of educational mission statements in America, see discussion below. 
primary goal the promotion of democracy, to be accomplished through direct community engagement, a focus on problem-solving, and an emphasis on collaboration between faculty and students (Woolard 2017, 47; Jacoby 2009, 11).

In the mid-late nineteenth century, the ways in which educational leaders conceptualized the civic benefit of higher education also began to change in important ways as American educational institutions increasingly modeled themselves on German universities with their amplified focus on disciplinary specialization and scientific research (Hartley 2011, 28). Instructors began to see their contributions to society primarily through their ability to use their expertise for the public good, rather than through their instructional “molding" of citizens (Peters 2010, 28). Thus strict codes of decorum, formerly seen as a key aspect in creating responsible citizens, were deemphasized, while intensified instruction in the natural sciences displaced subjects (for example, theology, classical literature) that formerly held a central place in higher education (Smith, Mayer, and Fritschler 2008, 30). This reorganization of priorities can be seen in the Wisconsin Idea, discussed above, where administrators positioned the key role of the university as the principal resource of information, analysis, and technical expertise for the governor and state legislature (Smith, Mayer, and Fritschler 2008, 38). As a result, modes of civic engagement in the late nineteenth and early twentieth centuries were framed largely in terms of providing technical and scientific expertise through governmental bureaucracies, while "direct" civic contributions (such as teaching and political activism) were subordinated.

The lofty ideals of America's early colleges and higher education in America's first hundred and fifty years were almost exclusively for white Christian men of European descent. Owing to the systematic exclusion of women and persons of color from early American "democratic" government, as well as various quotas on admittance of religious minorities, white Christian men comprised almost the entirety of those understood to be "citizens," and thus the potential civic leaders who required appropriate training. Barbara Jacoby has noted how this history proves problematic for those who might champion a focus on "citizenship" as part of civic engagement endeavors, a term that has historically functioned to exclude certain groups from mechanisms of political power and self-determination (Jacoby 2009, 9-10).

The founding of women's and historically black colleges in the nineteenth century, as well as Native American tribal colleges in the twentieth, began to make higher education accessible to a higher proportion of historically marginalized groups (Woody 1929; Solomon 1986; Stein 1992; Brooks and Starks 2011; Boyer 2015; Lovett 2015; Reyhner and Eder 2017; Nash 2018), but the civic engagement efforts of mainstream educational institutions continued to be restricted to a limited cross-section of the American polity. Thus, while colleges and universities held civic engagement as an ideal, they inherently limited the "civic" at which their lessons were aimed by narrowing the range of voices and perspectives that could be part of a broader project of creating an educated citizenry in a successful democratic country. This move continues to be significant in the contemporary American context, where the rights of citizenship and educational opportunities for undocumented American residents remain a hotly contested topic in American public discourse. Any contemporary efforts at the promotion of productive "citizenship" or civic "participation," then, will need to attend to the inequalities that have plagued historical definitions of citizenships and define clearly how their efforts address the contested boundaries of who constitutes the American "public."

Perhaps ironically, while increasingly narrow research expertise brought many benefits to American society, the universities' amplified focus on technocratic expertise stood in the way of or actively discouraged more direct forms of political or civic engagement. Many university administrators (not to mention political commentators) dissuaded instructors from engaging in direct political action, a fact underscored by the firing of many professors for engaging in political activism in the late nineteenth and early twentieth century (Smith, Mayer, and Fritschler 2008, 34-37; Lippmann 1932; Peters 2010, 48).

World War II and its aftermath led to major upheavals in American higher education. The United States government delivered largescale federal support for the nation's universities, beginning with support for the nation's scientists as part of the war effort but continuing in the post-war periods through initiatives such as the G.I. Bill and the National Defense Education Act (Smith, Mayer, and Fritschler 2008, 42). Thanks in part to this increased support, colleges began to serve much broader cross-sections of American society. In 1910, only about 4 percent of young adults (age eighteen to twenty-four) attended college; by the mid-twentieth century, that number was up to over 30 percent, and it would rise still higher to about 70 percent by 2005 (Smith, Mayer, and Fritschler 2008, 42). In response to fears regarding the spread of fascism in Europe, many leaders in American higher education renewed the call for education in civic leadership, with an express focus on training a new generation of leaders who would preserve America's democratic ideals (Musil 2015, 241). Thus Harvard's General Education in a Free Society (1945) and the Truman Commission's Higher Education for American Democracy (1947), both called for a renewed focus on fields such as history, art, literature, and philosophy in order to provide intellectual bulwarks against the ideologies that had undermined democratic governance in other parts of the world (Musil 2015, 242-43). These mid-century reform efforts led to important changes in higher education, as seen especially in general education curricula that emphasized interdisciplinary exposure to the natural sciences, social sciences, and humanities. And yet, despite stated 
ideals that remained in favor of civic engagement, many universities in practice downplayed this element of their mission (for example, by discouraging direct political activism, or by emphasizing research expertise with little expectation of civic application [Jacoby 2009, 11]).

In the 1960s, the Civil Rights and Vietnam War protests combined to create a robust atmosphere for direct political and civic engagement among students on campus across America (Lewis 2014, 58). Conservative backlash against campus activism, however,as seen especially with the successful gubernatorial run of future President Ronald Reagan in California-resulted in a heightened sensitivity by leaders in higher education to anti-activism critiques, which had the effect of creating an apolitical quiescence in many post-1960s universities (Smith, Mayer, and Fritschler 2008, 14, 67-68). The increasing disengagement of universities and colleges from civic purposes was exacerbated by changing demands from students; students in the 1970 s and 1980 s were increasingly viewing college chiefly in terms of career preparation, rather than civic or political engagement (Hartley 2011, 30).

\section{Modern Civic Engagement: Popularization, Pushback, and Persistence}

The late twentieth-century civic engagement movement was a response to this perceived lack of civic purpose among students in higher education. Taking their cue from 1960s-era organizations such as the Peace Corps and Volunteers in Service to America, many schools and universities in the 1980 s interpreted their commitment to civic engagement as community service, with programs designed to provide nonpartisan, largely nonacademic volunteer service opportunities for students (Lewis 2014, 58). At the same time, "a small group of educators began to emphasize a combination of community service and learning they called 'service-learning'" (Jacoby 2009, 11-12; Hartley 2011, 30-32; Woolard 2017, 18).

Yet, while community service and service learning have remained popular fixtures on many American college campuses, some educators have noted that service opportunities are inherently conservative: they rarely challenge colleges, universities, or local communities "to fundamentally change the ways in which they operate, thus preserving underlying assumptions and institutional behaviors" (Saltmarsh and Hartley 2011b, 10). Moreover, Peter Levine points out that community service does not necessarily train students in the types of deliberation, collaboration, and coalition building that are essential to communal flourishing and problemsolving (Levine 2014, 49).

As a result, some educational theorists have called for more direct forms of civic engagement. One such form is the the "liberative" approach championed by Paulo Freire and bell hooks (Pippin 2016; Posman 2016, 11; Myers et al., 2019). In her landmark work Teaching to Transgress, hooks draws upon critical feminist theory and her own teaching background in order to advocate for education as a "practice of freedom" that encourages students to "transgress" traditional social, cultural, and pedagogical boundaries (hooks 1994, 207). hooks calls on instructors to perform a non-hierarchical and participation-focused "engaged pedagogy" that empowers students to interrogate and challenge racial, social, and gender inequalities (hooks 1994, 15). In this way, hooks explicitly frames teaching and learning in higher education as a "counter-hegemonic act," or, "a fundamental way to resist every strategy of White racist colonization" (hooks 1994, 4, 171). hooks notes that her pedagogical approach "is an expression of political activism," which aims to "teach against the grain" of prevailing pedagogical approaches and cultural norms and "self-actualize" both students and instructors (hooks 1994, 15, 203). hooks' contribution to pedagogical theory lays bare the diversity of approaches to civic engagement in American educational history: hooks' emphasis on countering European colonial ideologies, for example, is a far cry from the early colonial colleges' emphasis on affirming such traditions.

Such calls for more "radical" engagement, however, have at times encountered extensive opposition from educators and governmental leaders. Some professors and political commentators have decried the supposed partisan politicization of the university and pushed for the disengagement of higher education from its civic-minded missions (Lippmann 1932; Bloom 1987; Kimball 1990; Fish 2008; Horowitz 2009; Horowitz and Laksin 2009; Horowitz 2010). ${ }^{2}$

This de-emphasis on civic value has often gone hand-in-hand with a push to make higher education more focused on providing "market-centered," rather than civic-minded, educational offerings. Business-focused education has a long history in America; the founders of Brown University (est. 1764) explicitly stated that the college would "be a means of bringing great quantities of money" into the surrounding area (Hartley 2011, 28). The most recent focus on the economic impact of higher education can be traced to the 1980 , when the intense fiscal pressures of the late 1970 s and early 1980s, combined with the increased accessibility of higher education to lower-income students, led to a surge in pre-professional training and degrees. This strand of educational thought has continued to the present day. E. Sparks and M.J. Waits' Degrees for What Jobs? (2011), for example, recommends that higher education's funding

2 For further discussion of "politics" and "partisanship" in the academy, see discussion in Upson-Saia and Doerfler (2020). 
should depend on "economic goals," "workforce preparation," and "competitive advantage” (Sparks and Waits 2011, 3; Musil 2015, 244). Politicians have often championed similar lines of reasoning both in order to justify cuts to higher education funding and to propose their own educational "reforms." Scott Walker, governor of Wisconsin from 2011 to 2018, proposed removing the phrases "the search for truth" and "improve the human condition" from the charter of the University system of Wisconsin, which draws its language from the famous Wisconsin Idea (see above) (Musil 2015, 244). Various state Governors have proposed eliminating programs such as women's studies and anthropology (Musil 2015, 244), while former President Barack Obama used market-based logics to question the value of an art history degree in comparison to skills training (Jaschik 2014). These critiques do not necessarily represent the views of a majority of American citizens or students, as survey results have often shown high demand for broad-based curricula that feature a diverse range of subjects (Musil 2015, 245). And yet, as a response to these trends, many educational administrators softened their promotion of the (non-monetary) civic values of higher education, even while those values remained central and explicit features of college and university mission statements (Hartley 2011, 29).

University and college mission statements provide important institutional contexts for contemporary articulations of civic engagements. Mission statements, at least theoretically, are the product of collective discussion about the purpose of the university, and they are one important way that universities communicate to a broader audience. A brief survey of a diverse range of mission statements from four-year colleges highlights the ways that university leaderships explicitly name and explain the university's role in creating an educated citizenry and contributing to society at large. We have chosen to highlight universities in two states with very different political and economic cultures: Texas and California. And within these states, we have chosen to examine an elite private research university, a private religious university, and two large public universities offering a range of approaches produced by different stakeholders for different constituencies. In this discussion of the history of civic engagement, we have traced the ebbs and flows of the prioritization of civic engagement, and the range of ways that it has been enacted in university curricula, and yet, as the mission statements of these four very different universities demonstrate, the aim of cultivating a responsible and engaged citizenry is perhaps surprisingly consistent.

Stanford University, a private research university in Palo Alto, California, offers an articulation of each of its schools' missions in their respective About pages. Stanford's School of Humanities and Sciences' About page focuses on forming engaged members of a dynamic society rooted not only in the past but the present and future: "All undergraduates take a range of courses in $\mathrm{H} \& \mathrm{~S}$ that challenge them to think critically about the world and their roles in it. Graduate students work alongside world-renowned faculty to pursue and shape foundational research that leads to breakthroughs and discoveries that shed new light on the past, influence the present, and shape the future" (Stanford University 2020). Stanford's mission statement explicitly articulates preparing students to engage with the present and future world, not by relaxing classroom standards or minimizing content but through critical thinking and research.

Where Stanford is unaffiliated with a religious denomination, St. Mary's University is a small Catholic and Marianist liberal arts university and a Hispanic-Serving Institution (HSI). St. Mary's focuses on forming students as engaged members of their local and global communities, and roots that focus in its religious identity: “St. Mary’s University, as a Catholic Marianist University, fosters the formation of people in faith and educates leaders for the common good through community, integrated liberal arts and professional education, and academic excellence" (St. Mary's University 2020a). The Marianist charism includes the goals of educating for service, justice, and peace, and educating for adaptation and change, emphasizing both dynamism and community activism.

Small private universities are not the only ones which emphasize civic engagement as one goal of an excellent education. Both the University of California and Texas A\&M, large public-research university systems and land-grant universities, frame their missions in terms of service and adaptability. Texas A\&M “is dedicated to the discovery, development, communication, and application of knowledge in a wide range of academic and professional fields. . . . It prepares students to assume roles in leadership, responsibility and service to society . . . it addresses the needs of an increasingly diverse population and a global economy" (Texas A\&M University 2020). The UC system promises that "instructional programs at the undergraduate level transmit knowledge and skills to students, ... Education for professional careers, grounded in understanding of relevant sciences, literature, and research methods, provides individuals with the tools to continue intellectual development over a lifetime and to contribute to the needs of a changing society" (University of California 2020). That students need to be able to contribute to a diverse and dynamic world is assumed in both of these mission statements.

Though California and Texas are states with rather different cultures, and though public and private universities have distinct challenges and roles within their communities, all four of the university mission statements' surveyed emphasize the goal of preparing students to serve and lead a dynamic society with diverse populations and many possible futures. Their framings are certainly different: two are rooted in their histories as land-grant universities meant to serve their local communities, one is rooted in a faith identity, and 
one is both rooted in its industrialist and assimilationist past and explicitly moving beyond it. And yet, in all four cases it is clear that a commitment to civic engagement is integral to the ways that universities present their mission and role to the public through official university websites. Further, the commitment expressed in the various mission statements moves beyond words; all four universities have university offices and full-time staff whose job it is to support civic engagement in and out of the classroom. ${ }^{3}$

While so often faculty and administrators perceive engaging with modern political issues and frameworks as antithetical to a traditional education, marked as either crucially or dangerously transgressive, at its core, this contemporary engagement is the fulfillment of the promise that universities themselves lay out in their statements of identity and mission. Civic engagement is fundamental to how universities communicate who they are to their own community and to outsiders. Consistent with the chronology discussed above, these articulations of civic engagement are also fundamentally political, advocating for constructive engagement in the polity. To engage thoughtfully with the world, one must understand both the present and the narratives of the past that have created it.

Despite the consistency of stated university commitments to civic engagement, the critics of this educational aim are still loud. American philosopher Martha Nussbaum has responded to these debates by suggesting that profit-focused educational approaches are shifting American higher education away from its intended purpose, which is the training of "complete citizens who can think for themselves, criticize tradition, and understand the significance of another person's suffering and achievements" (Nussbaum 2010, 2). According to Nussbaum, America is in an "educational crisis" that could precipitate major threats to American democratic ideals (Nussbaum 2010, 2). In response, Nussbaum argues that higher education should return to its humanistic and liberal arts roots in order to promote more inclusive forms of citizenship, with a particular focus on cultivating skills in empathy, accountability, and critical thought (Nussbaum 2010, 7, 43-44). For Nussbaum, this entails appropriate curricular emphases (for example, global literacy, foreign languages, history, geography, philosophy) and pedagogical methods (for example, "Socratic pedagogy") (Nussbaum 2010, 54, 86-90). Nussbaum highlights an “understanding of the world's many religious traditions" as a particularly important subject area, noting, "There is no area (except, perhaps, sexuality) where people are more likely to form demeaning stereotypes of the other that impede mutual respect and productive discussion” (Nussbaum 2010, 83).

Nussbaum's treatment represents a forceful argument for the renewal of civic-minded approaches in higher education. And yet, it also serves as a reminder of the complex and contested history of civic engagement in America, as well as its long-standing imbrication in broader political structures and movements. Any argument for or against particular modes of civic engagement, therefore, is an historically-situated and inherently political enterprise. In advocating for or contesting against certain forms of civic engagement, or in making strategic choices in civic engagement planning, participants are inevitably assigning, choosing, interpreting, reproducing, and contesting particular civic values, interests, missions, and goals that have ramifications for a diverse range of peoples and communities (Peters 2010, 7; cf. hooks 1994, 203). This is not to say, of course, that civic engagement is inherently partisanalthough some iterations will certainly correlate to the aims of certain political parties or constituencies-but to argue that recent calls for the "divorcing" of the political from education are inherently self-contradictory, illusory, and ultimately impossible. The history of civic engagement in America demonstrates that even supposed apolitical education-for example, an exclusive focus on servicelearning, or the championing of purely economic gains-effectively acts as a political choice by privileging certain kinds of political engagements (or lack thereof) over others. The task for educators today, then, is not to choose whether or not their classrooms will be political (see Fruchtman and Park 2020). Rather, the choice before us is what form of political engagement our courses will undertake.

\section{Civic Engagement and Religious Studies}

Especially in light of the contested political terrain surrounding higher education. some instructors in religions of antiquity may worry about explicitly integrating civic engagement into their own course planning. Does such teaching run the risk of politicizing the "apolitical"? Or promoting anachronistic readings of historical cultures? What do contemporary politics have to do with antiquity, anyway? Despite such challenges, mindful incorporation of civic engagement pedagogy provides important opportunities to demonstrate that religious studies are fulfilling the key missions of our respective institutions.

Incorporating civic engagement into our pedagogy also fulfills the key missions of religious studies. What is the point of taking a course in religious studies? What is the point of taking a religious studies course focusing on late antiquity? Religious studies offers the context that students need to understand how and why our current world looks the way it does, and to explore alternative

\footnotetext{
3 See Stanford University Haas Center (2020) and St. Mary's University's Office of Civic Engagement (2020b). Each campus in the Texas A\&M and University of California system has its own office which offers civic engagement opportunities.
} 
possibilities. Beyond the explicitly religious, the interdisciplinary nature of religious studies offers tools and strategies to understand wider societies, cultures, and interactions. Religious studies explores the narratives that communities tell in order to make meaning of their world, and the ways that those narratives are interpreted and adapted to respond to new successes or challenges. It explores the questions that individuals and communities have asked about their lives and worlds in different cultures, continents, and historical periods, and examines the different answers they have each offered, contextually. At its core, religious studies prepares students to be critical thinkers who understand the structures, texts, and histories which continuously create the world in which we live. We aim to familiarize students with the worldviews, practices, and values of religious communities. Without asking students to subscribe to any form of religiosity, we do expect them to appreciate the grounds on which peoples' religiosity enables them to make meaning of the world and to make sense of their place in the world. ${ }^{4}$

As scholars of religion in late antiquity, we are ideally positioned to guide students in exploring such issues. We teach courses that, on the one hand, often explore traditions with which many students in the United States have personal familiarity or investments (for example, Judaism, Christianity, and Islam, among others), thus creating natural points of entry by which to engage students with such inquiries. On the other hand, our focus on a time period relatively distant from our own, and which is not organized around a scriptural canon, provides opportunities for encountering what many students may perceive as religious "otherness," even within otherwisefamiliar traditions. The dual familiarity and foreignness of late antique religion creates distinctive opportunities for developing cultural and historical literacy alongside a kind of critical empathy.

Those of us who focus on the late antique world attempt to instill in students knowledge about the past, but we also aim to develop students' ability to situate textual and material evidence within its context. In so doing, students discern how an individual's or a community's worldviews, practices, values, priorities, and anxieties are informed by their circumstances. Contextualization enables students to better understand how different views and behaviors could emerge within a society, particularly with respect to where one stood in the society's power structures. Additionally, students are asked to cultivate their historical imagination by filling in the plausible reasoning of subjects for whom we have little extant evidence in the historical record. In short, scholars of religion in late antiquity aim to instill in students an ability to charitably inhabit the experience of others-across time and culture-and to understand why their positions were reasonable within their context and their station in society (Educational Resources Information Center 1991, 175-176).

Professional organizations of religious studies and history frame these shared aims in terms of the social good. The American Historical Association, for instance, argues that practices in historical thinking are “central to engaged citizenship." Students' “engage[ment with] a diversity of viewpoints in a civil and constructive fashion” are transferable skills: not only across historical distance, but also across cultural divides (American Historical Association 2016). In religious studies, as students gain practice in familiarizing themselves with unfamiliar others, their aversion to (sometimes frightening and threatening) encounters with difference softens, giving way to an aspiration to understand people unlike themselves (Educational Resources Information Center 1991, 175-176). As such, the academic study of history and religion form orientations and habits of deliberation that serve students well when they encounter difference in our pluralistic world, in turn enriching their ability to engage in society characterized by diversity. ${ }^{5}$

Beyond these disciplinary aims, faculty often also bring more nebulous, attitudinal aims into the classroom: a desire for students to be engaged in a subject that the professor believes is important, a desire for students to become interested enough to sign up for another course in the discipline, a desire for students to take what they are learning in the classroom and continue to reflect upon it outside of the course, a desire for students to be able to apply - and be interested in applying-what they are learning to new texts and contexts. These are attitude-based student learning objectives. While these learning objectives may be difficult if not impossible to measure, they often underlie the goals that engaged and committed faculty bring to a course. And for students to be engaged and interested in applying what they learn to new contexts, for students to believe that the work in our classrooms is relevant to new contexts, we have to make the connections between what we teach-religion in late antiquity-and the world we live in explicit.

\footnotetext{
4 On this central tension within religious studies and its impact on the classroom, see Pearson (2016). For more on the distinctive contributions of religious studies courses to civic engagement, see Posman and Locklin (2016).

5 Student learning objectives clarify for both faculty and students what knowledge and skills they will be mastering in a given course, and offer criteria for what successful mastery will look like (Mager 1997; Faulconer 2017). Many universities now require student learning objectives to be articulated in syllabi; degree programs and schools may also develop curricular student learning objectives. Indeed, the Association of American Colleges and Universities (AACU) has articulated its own "Essential Learning Outcomes" that it believes are the hallmarks of a twenty-first-century liberal education (AACU 2020). Among the learning outcomes that the AACU articulates are: "inquiry and analysis," "critical and creative thinking," "information literacy," both local and global "civic knowledge and engagement," and "ethical reasoning and action" (AACU 2020). What are these outcomes if not civic engagement? For more on student learning outcomes, with specific reference to biblical studies, see Webster et al. (2012). For courses or pedagogical strategies directly engaging with themes of difference and diversity in a global religious context, see Ramye (2006), Eilers (2014), DeTemple (2012), Corrie (2013), King (2016), Wiersma (2016), Derris and Runions (2016).
} 
As was noted in Upson-Saia and Doerfler's (2020) essay, these outcomes are not only the goals or objectives of a faculty disconnected from the needs and experiences of their students. Surveys of current high school and college students suggest that today's incoming students are expecting a college education that is engaged in real-world issues and that prepares them for meaningful careers that will "have a positive impact on the world" (Seemiller and Grace 2014, 103-104). And indeed, studies have shown that students were more engaged, and thus learned better, "when they thought the curriculum was relevant to real-life issues" (Engstrom 2008, 11, quoted in Gabriel 2018, 38).

If civic engagement is embedded in the mission of the university as a whole as well as in the field of religious studies, how can religious studies faculty integrate it more explicitly into our pedagogies? We offer here three models for consideration: explicit naming, civic skill-building, and community-based learning. These models are ordered from lowest to highest in terms of professor and student effort.

\section{Naming}

At the most basic level, a professor can foster civic engagement in the classroom by naming the ways that the texts and topics explored already engage with broader issues of societal relevance. This strategy can be as simple as noting the ways race, class, gender, power, enslavement, or state-sanctioned violence are described in an ancient text, or the ways that concerns about race, class, gender, power, enslavement, or state-sanctioned violence have shaped the ways that ancient texts have been interpreted, prioritized, and taught. ${ }^{6}$ It can also include calling attention to the diversity of voices included on your syllabus, and the range of racial and religious backgrounds of those who produce the scholarship of our respective fields. ${ }^{7}$ And if that is impossible because our syllabi are predominantly or exclusively made up of the scholarship of white men, it should include thinking seriously about what important scholarly voices and perspectives we are keeping from our students.

The authors of this set of articles all participated in a workshop on "Politics, Pedagogy, and the Profession," which took place immediately after the $2017 \mathrm{AAR} / \mathrm{SBL}$ annual meeting. In the spirit of naming, the present authors want to name the fact that the majority of participants who were interested in writing articles based on our initial conversations and ongoing research are white. Yet fostering civic engagement is particularly important for white faculty. This identity comes with significant privilege but also, ideally, great responsibility. Koritha Mitchell has described her own experience as a black, female tenured professor: "My very presence makes some of my students uncomfortable because I do not fit any picture society has given them of an expert. My students, after all, have grown up bombarded with the message that people who belong in authority-especially authority based on intellectual accomplishments and expertise-are men, usually white men" (Mitchell 2015). The invisible labor that faculty of color, faculty from working-class backgrounds, and queer faculty do-in mentoring minority students, in serving on diversity-themed committees, and in diversifying a range of campus communities-is important but it is also exhausting and unsustainable (Matthew 2016; Social Sciences Feminist Network Research Interest Group 2017). White faculty may be able to avoid complex classroom discussions about race, class, gender, and other issues important to both ancient and modern life, but must not, because it puts an undue burden on faculty of color, and inherently impoverishes student and faculty understanding of the ancient world and the processes of knowledge that have led to modern understandings of it (see also Upson-Saia and Doerfler 2020).

One participant in the workshop, Timothy Luckritz Marquis, taught a seminary course called "Ethnicity, Race, and New Testament Interpretation" at Moravian Theological Seminary, which named and explored these ideas in a range of historical contexts. His course learning objectives included discussions of "themes of ethnicity and race in early Christian writings, in large part by contextualizing them within Greek and Roman (including Jewish/Judean) ethnic discourses" as well as examinations of "how biblical themes of ethnicity were interpreted throughout Christian history as a part of developing Western concepts of ethnicity and race" (Luckritz Marquis 2018b, 1). Students read extensively from Greek and Roman writers, biblical texts, and modern scholars working to understand the complicating cultural constructions of ethnicity and race in the ancient world, and integrated them through class discussions and activities. ${ }^{8}$ These readings were directly tied both to the history of biblical interpretation, and to the work that the seminarians would do doing upon graduation. Students engaged with these texts and ideas, and reported that course materials were "very useful" (private correspondence, 8/28/2018).

\footnotetext{
6 For specific explorations of pedagogical approaches to racial justice, see Teel (2014).

7 For broader explorations of inclusive pedagogies, see Dallalfar, Kingston-Mann, and Seiber (2011). Broaching such subjects, of course, does not come without its own challenges. On these issues, see especially Byron (2012) and Scheid and Vasko (2014). For an example of interrogating the inclusion of particular "voices" in graduate-level classrooms, see Wright (2019).

8 For a description of one classroom activity that Luckritz Marquiz used, see Luckritz Marquis (2018a).
} 
Even faculty who do not want to offer an entire course on one of these topics can name where race, ethnicity, gender, personal status, and class appear in the texts that we assign-naming Philemon's status as an enslaved person, articulating the Mishnah's complicated understanding of gender and sex, or communicating the ways that early Church Fathers associated Blackness and the demonic (Shanks-Alexander 2013; Brakke 2009, 157-181). Turning the students' attention to scholarship itself, we might also articulate those areas of research and teaching where minoritized or marginalized identities have too often been neglected. For her course on early Christian gospels, for example, Gay Byron forefronts discussion of the oft-ignored Axumite Empire, drawing attention both to scholarly lacunae as well as the distorting effects of the "mono-optic" lenses through which teachers and students typically encounter ancient cultures (Byron 2012, 110). Byron begins class by showing her students maps that might be used to contextualize the New Testament and early Christian literature, juxtaposing those that focus exclusively on the Roman Empire with alternatives that incorporate its Axumite neighbor, thus creating for students a visual representation of the cultures and knowledges that are typically neglected within historical contextualizations of early Christianity (Byron 2012, 2010). As showcased by Byron, forefronting marginalized identities might take the form of a single class activity, but these activities can frame a semester's encounter with the ancient world. Many of our students are not yet trained to see these elements in the "classical texts" that they read; modeling how to do so-on both a small and large scale-is an important pedagogical task we can undertake. This is an equally important pedagogical task for students who are attuned to seeing these elements in classical texts; our silence on these issues may be read by some students as approval.

\section{Building Skills In Civic Engagement}

In addition to naming issues related to cultural literacy, it is essential to train students in skills that will enable their civic engagement and participation even beyond their undergraduate experience. ${ }^{9}$ Many skills could be highlighted here as important, but one area that is certainly essential is media literacy and criticism. Our focus here on skills reflects our belief that in order to form a more perfect civil society, it will not just be important to communicate particular types of content, but also to expose students to the processes of critical thinking, criticism, coalition-building, collaborative decision-making, and problem-solving which are so fundamental to a liberal arts education. A focus on process, moreover, has the potential to promote political engagement without necessarily promoting a particular political end. ${ }^{10}$ This approach, of course, is not apolitical, but inherently political in its championing of the thinking that promotes democratic decision-making and empowerment.

In today's ever-changing media landscape, skills in media literacy and criticism are essential. The forms and methods by which citizens (including students) access information is rapidly expanding and challenging the traditional media landscape in numerous ways. As was made especially clear by the controversial role of social media outlets like Facebook in the 2016 U.S. presidential election, the proliferation of media outlets across the internet has allowed misleading, unverified, or empirically false news stories to proliferate with little resistance. This propagation of "fake news," has, in turn, been ripe for manipulation by opportunistic politicians, who have used the uncertainty of new media landscapes to discredit unfavorable media coverage. Problems regarding falsified or misleading news stories will only become worse: advancing technologies in voice and video manipulation will soon make fabricated audio and video clips of important figures nearly indistinguishable from their authentic counterparts. ${ }^{11}$ This represents a direct challenge to civil action and democracy, as an informed public and voting citizenry is essential to the operations of a healthy democratic government. Important endeavors such as The News Literacy Project (2020) have already been launched to combat misinformation in the media, but it will be essential for future liberal arts classes to train students in the skills of discerning reliable sources of information, including fact-checking, source comparison, discerning of source provenance, and authorial attribution, among others.

Scholars of religion and antiquity have a distinctive set of perspectives and skills to bring to this conversation, as the fields of ancient history, biblical studies, and religious studies have long engaged in debates over the authenticity and reliability of their primary source documents. ${ }^{12}$ One needs only to peruse a commentary on the Book of Acts, any monograph on the Deutero-Pauline Epistles, or the recent debates over the so-called Gospel of Jesus' Wife to realize that issues of authorship, sources, provenance, and reliability inevitably bubble to the surface in nearly every discussion of ancient texts. With this as a backdrop, scholars of antiquityand especially religious texts of antiquity, whose provenance has often been a source of significant debate within and out of the communities that hold them dear-have a unique opportunity to bring their skills to bear on the challenges facing students and other citizens in our ever-evolving media landscape. Instructors have the opportunity to lead their students in informed and engaging discussions of questions of both ancient and contemporary relevance: how do you determine where a source came from? Who

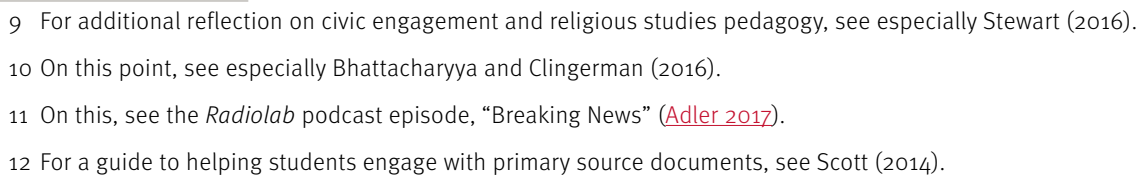


authored this treatise or article? How can we compare sources to determine which is reliable? What differentiates a reliable source from an unreliable one? How can you tell if a source is "forged," or contains mistaken information? How do you "synthesize" sources in order to reconstruct a historical event? What constitutes "proof"?

Scholars of antiquity here can introduce students to the methods we have developed or co-opted in answering such questions, including source criticism, redaction criticism, literary-historical criticism, stylometry, paleography, handwriting analysis, and radiocarbon dating, among others. The recent controversy over the Gospel of Jesus' Wife provides an opportunity, for example, to explore how tools such as stylometry, paleography, and redaction criticism played integral roles in scholarly disputes over the text's provenance. Sonja Anderson of Carleton College has created a handout with tips for reading ancient texts, which she has shared with her students in several of her classes. The tips she enumerates there-familiarize yourself with the author and history, do not assume that today's "common sense" was common in ancient texts, read slowly, determine the genre of the text and be aware of its conventions, watch for implicit and explicit polemic, map the argument, assume particularity in each text, draw connections, annotate-are skills that are important in understanding ancient texts and are equally crucial in understanding modern texts. In a course on women and gender in the Hebrew Bible, Sara Ronis pairs Anderson's handout with a writing assignment in which students choose several of the strategies listed, and then write reflections about their reading experience using these strategies on assigned texts. By becoming familiar with these methods of analysis through case studies of ancient texts, students are better prepared to adapt or invent methodologies for critically interpreting contemporary media.

In-class activities can also be an important part of promoting heightened media literacy. Scholarly debates over ancient "forgeries," for example, provide prime opportunities for collaborative in-class team debates, where teams of two to four students form opposing sides and, through a set of structured components (for example, Opening Statement, Rebuttal, Class Q\&A, Closing Statement), dispute a shared prompt. In the case of ancient forgeries, students can debate the pseudepigraphic status of ancient texts of contested authenticity (for example, 2 Thessalonians, Secret Gospel of Mark, 1 Timothy, and so forth), and over the course of a class period, can learn from their own debates as well as from those of their classmates. Requiring students to conduct such debates encourages many skills that are conducive for democratic civic processes-including evidence analysis, collaborative problem-solving, public presentation, understanding opposing arguments, persuasive speech, and deliberative discourse. ${ }^{13}$ Travis Proctor has conducted numerous debates as part of courses on Christian origins, and student evaluations have frequently commended this aspect of courses as one of the most challenging yet rewarding course units. These are activities and assessment activities that take up one to two class periods, and yet their educational pay-off is much larger. Student learning improves, their critical reading and thinking skills are strengthened, and their senses of expertise and ownership of the ancient materials is enhanced. Such activities take on added importance in a contested media landscape, as students' ability to analyze (and perhaps defend) particular media outlets will be of paramount importance for solving problems of common concern.

\section{Community-based Learning}

Instructors promote civic engagement not only within the classroom, but also by integrating the classroom with the wider community. Community-based learning is an umbrella term for "any pedagogical tool in which the community becomes a partner in the learning process" (Mooney and Edwards 2001, 181 n. 2). It is not identical to civic engagement, but it is one form of civic engagement. At its core, community-based learning is based on two premises: first, that student learning is enhanced when students are asked to apply what they are learning to non-university communities and contexts, and second, that "all communities have intrinsic educational assets and resources" with much to offer students, faculty, and curricula (Great Schools Partnership 2014; see also Garoutte 2018). Community-based learning "includes but is not limited to community-based or action research (research done in partnership with the community), direct service (students provide assistance to community members), and advocacy work both on and off campus" (Garoutte 2018, 149). Community-based learning is usually a substantial part of a course's structure and organization, coheres with a course's general themes, and is often integrated in course lectures and class discussions, as well as writing assignments and other forms of assessment.

Community-based learning can enable students to develop their critical thinking and problem-solving skills, synthesize "information from class and the 'real world,"' build awareness of the structures and systems that create particular community realities, and apply the "discipline-specific theory and methodological skills" they are learning in the classroom to new experiences outside the classroom

\footnotetext{
13 It is important to note that an overemphasis on public speaking or deliberative discourse can sometimes privilege those from social groups that have traditionally been accorded greater freedom of expression within American public spaces, while discouraging contributions from historical dispossessed groups (for example, women, people of color). As such, we encourage instructors to supplement deliberative discourse with reflection on the historical circumstances that have contributed either to the centralization or marginalization of particular voices within democratic processes (or governance more generally).
} 
(Mooney and Edwards 2001, 189). It can also improve student understanding and engagement within the classroom itself (Morton 2009, Garoutte 2018). Community-based learning is relatively common in the social sciences, and in college capstone courses (Mooney and Edwards 2001, Morton 2009, Garoutte 2018, Arthur and Newton-Calvert 2015). However, it also has significant potential to be used in the religious studies classroom.

Indeed, some religious studies and theology faculty are already integrating community-based learning into their courses. ${ }^{14}$ For example, Ronis integrated community-based learning into a course she taught in Fall 2017 called "Home, Exile, and Diaspora in the Hebrew Bible." The course examined the development of the Israelite states, forced migration and the Babylonian exile, and finally the internal crises that emerged when the Babylonian exiles returned to Jerusalem. The student learning objectives for the course included the goals that students "be familiar with major stories and texts about home, exile, and diaspora in the Hebrew Bible," "understand how experiences of immigration and exile shaped the formation of the Hebrew Bible," and "be able to make connections (including both similarities and differences) between the biblical experience of exile and migration and the experiences of modern immigrants."

To achieve these objectives, and with the support of her university's office of civic engagement, Ronis required students to spend nine to twelve hours over the course of the semester working with one of several organizations offering services to immigrants in San Antonio. Her students tutored elementary and high school students, assisted ESL classes for adults, and watched infants and toddlers so that their parents could attend meetings and classes. Students reflected on their experiences and encounters, analyzed relevant biblical texts, and applied their new knowledge both to new texts and new areas of engagement through journaling, discussions in class and on the class discussion board, and a take-home final exam. In light of these experiences, they analyzed letters to the editor about immigration and refugees and assessed the ways that texts from the Hebrew Bible are deployed across the political spectrum in debates about immigration. Rather than essentializing or conflating all experiences of being an immigrant, these experiences enabled students to reflect on the systemic reasons that very different immigration experiences exist. ${ }^{15}$ Communitybased learning did not replace classroom lecture or discussion but enhanced it; students developed their skills of critical reading and thinking, both with the biblical texts and with the diverse ways that those texts continue to be interpreted.

Other fruitful areas for community-based learning relating to ancient texts and traditions might include work within a local prison in a course on martyrdom and/or the Pauline letters, working with LGBTQIA+ organizations in a class on gender and sex in the ancient world, and working with public relations officers and speechwriters for local political candidates in a course on ancient religious rhetoric. When instructors connect these experiences to relevant course materials, and give students multiple ways to reflect on the experience and its connections to course content, instructors enhance both student learning in their subject area and civic engagement more broadly.

Community-based learning must be approached with an awareness of the ethics of partnering with community organizations, potential imbalances of power and resources, a commitment to listening "to what the community partners' needs are and to balance that with student learning and curricular needs," (Kerrigan, Reitenauer, and Arevalo-Meier 2015; Garoutte 2018, 156-157), and a commitment to make sure that programming and students are not simply "exploiting community partners, who are made to give time and energy to helping college students rather than working toward their own institutional and community goals," for their own learning or resumebuilding (Garoutte 2018, 157). ${ }^{16}$ University offices of civic engagement can help faculty and community partners create a learning experience that is productive, and respectful for students and the community as a whole. External organizations such as CIRCLE (The Center for Information and Research on Civic Learning and Engagement) and Campus Compact can offer additional support for faculty at institutions where offices of civic engagement are absent or under-resourced.

\section{Conclusion}

For as long as American universities have existed, they have fostered and prioritized civic engagement in some form. The term itself is dynamic, and offers multiple points of entry for the scholar-teacher. As scholars and teachers of religious studies, we are wellsituated to prepare our students to engage in the dynamic and complex world in which we and they live. This work is important-to

\footnotetext{
14 For additional examples of courses in religious studies engaging in civically-engaged or community-based learning, see Runions (2012), Vasko (2017), Patterson et al. (2015), Wingeier-Rayo (2016), and Rademacher (2016).

15 For comparable reflections on incorporation themes of the "stranger" and "hospitality" into the religious studies classroom, see Delaporte (2016).

16 For additional reflections on the challenges inherent in this kind of community-based learning, especially with regard to race, see Reed-Bouley and Kyle (2015) and Perkinson (2012).
} 
the university, to us, and to our students. And this work is doable, with a range of ways of doing it that require more or less effort on the part of a teacher. What was true to fourth-century Babylonian rabbis is perhaps even more true today-education is key to the survival of the polity.

\section{BIBLIOGRAPHY}

Adler, Simon (producer). 2017. “Breaking News” (audio podcast). Radiolab by Jad Abumrad and Robert Krulwich, July 27. New York, NY: WNYC Studios. https://www.wnycstudios.org/podcasts/radiolab/articles/breaking-news.

American Historical Association. 2016. “Tuning the History Discipline.” https://www.historians.org/teaching-and-learning/tuningthe-history-discipline/2016-history-discipline-core.

Arthur, Deborah Smith, and Zapoura Newton-Calvert. 2015. "Online Community-Based Learning as the Practice of Freedom: The Online Capstone Experience at Portland State University.” Metropolitan Universities 26 (3): 135-157. https://pdxscholar. library.pdx.edu/cgi/viewcontent.c gi?article=1007\&context=studies fac.

Association of American Colleges \& Universities (AACU). 2020. “Essential Learning Outcomes.” Association of American Colleges \& Universities. https://www.aacu.org/leap/essential-learning-outcomes.

Bhattacharyya, Swasti, and Forrest Clingerman. 2016. "Political Involvement, the Advocacy of Process, and the Religion Classroom." In Teaching Civic Engagement, Forrest Clingerman and Reid B. Locklin, eds., 205-223. New York, NY: Oxford University Press.

Bloom, Allan. 1987. The Closing of the American Mind. New York, NY: Simon \& Schuster.

Boyer, Paul. 2015. Capturing Education: Envisioning and Building the First Tribal Colleges. Pablo, MT: Salish Kootenai College Press.

Boyte, H.C., and N.N. Kari. 2000. "Renewing the Democratic Spirit in American Colleges and University." In Civic Responsibility and Higher Education, 37-59. Westport, CT: The Oryx Press.

Brooks, F. Erik, and Glenn L. Starks. 2011. Historically Black Colleges and Universities: An Encyclopedia. Santa Barbara, CA: Greenwood.

Byron, Gay L. 2012. “Race, Ethnicity, and the Bible: Pedagogical Challenges and Curricular Opportunities.” Teaching Theology and Religion 15, no. 2: 105-124. https://doi.org/10.1111/j.1467-9647.2012.00778.x.

Clark, Elizabeth. 2011. Founding the Fathers: Early Church History and Protestant Professors in Nineteenth-Century America. Philadelphia, PA: University of Pennsylvania Press.

Clark, Elizabeth. 2018. The Fathers Refounded: Protestant Liberalism, Roman Catholic Modernism, and the Teaching of Ancient Christianity in Early Twentieth-Century America. Philadelphia, PA: University of Pennsylvania Press.

Corrie, Elizabeth. 2013. "From Civic Engagement to Circles of Grace: Mid-Range Reflection on Teaching for Global Citizenship.” Teaching Theology and Religion 16, no. 2: 165-181. https://doi.org/10.1111/teth.12028.

Dallalfar, Arlene, Esther Kingston-Mann, and Tim Seiber, eds. 2011. Transforming Classroom Culture: Inclusive Pedagogical Practices. New York, NY: Palgrave MacMillan.

Delaporte, Marianne. 2016. “Giving and Receiving Hospitality during Community Engagement Courses.” In Teaching Civic Engagement, Forrest Clingerman and Reid B. Locklin, eds., 61-73. New York, NY: Oxford University Press. 
Derris, Karen, and Erin Runions. 2016. "More than Global Citizenship: How Religious Studies Expands Participation in Global Communities." In Teaching Civic Engagement, Forrest Clingerman and Reid B. Locklin, eds., 184-204. New York, NY: Oxford University Press.

DeTemple, Jill. 2012. "Home is My Area Code: Thinking About, Teaching, and Learning Globalization in Introductory World Religions Classes.” Teaching Theology and Religion 15, no. 1: 61-71. https://doi.org/10.1111/j.1467-9647.2011.00764.X.

Educational Resources Information Center. 1991. "Religion." Reports from the Fields: Project On Liberal Learning, Study-In-Depth, and the Arts and Sciences Major: Liberal Learning and the Arts and Sciences Major, volume 2, 169-183. Washington, DC: Association of American Colleges.

Engstrom, Cathy McHugh. 2008. "Curricular Learning Communities and Unprepared Students: How Faculty Can Provide a Foundation for Success.” New Directions in Teaching and Learning 115: 5-19. https://doi.org/10.1002/tl.322.

Eilers, Kent. 2014. "Hermeneutical Empathy: Receiving Global Texts in Local Classrooms.” Teaching Theology and Religion 17, no. 2: 165-166. https://doi.org/10.1111/teth.12185.

Faulconer, Emily Kaye. 2017. “Increasing Student Interactions with Learning Objectives.” Journal of College Science Teaching 46 (5): $32-38$.

Fish, Stanley. 2008. Save the World on Your Own Time. New York, NY: Oxford University Press.

Fruchtman, Diane Shane, and Chan Sok Park. 2020. "Accepting the Inevitability of Politics in the Classroom: A Proposal for How to Identify Best Practices in Effective and Inclusive Religious Studies Pedagogy." The Wabash Center Journal on Teaching 1 , no. 3: 57-72. https://doi.org/10.31046/wabashcenter.v1i3.567.

Gabriel, Kathleen F. 2018. Creating the Path to Success in the Classroom. Sterling, VA: Stylus Publishing.

Garoutte, Lisa. 2018. “The Sociological Imagination and Community-based Learning: Using an Asset-based Approach.” Teaching Sociology 46 (2): 148-159. https://doi.org/10.1177/0092055X17750453.

Great Schools Partnership. 2014. "Community-Based Learning." The Glossary of Education Reform, March 3. https://www.edglossary.org/community-based-learning/.

Hartley, Matthew. 2011. "Idealism and Compromise and the Civic Engagement Movement." In "To Serve a Larger Purpose": Engagement for Democracy and the Transformation of Higher Education, 27-48. Philadelphia, PA: Temple University Press.

hooks, bell. 1994. Teaching to Transgress: Education as the Practice of Freedom. New York, NY: Routledge.

Horowitz, David. 2009. Indoctrination U: The Left's War Against Academic Freedom. New York, NY: Encounter Books.

Horowitz, David. 2010. Reforming Our Universities: The Campaign for the an Academic Bill of Rights. Washington, DC: Regnery Publishing.

Horowitz, David, and Jacob Laksin. 2009. One-Party Classroom: How Radical Professors at America's Top Colleges Indoctrinate Students and Undermine Our Democracy. New York, NY: Crown Forum.

Jacoby, Barbara. 2009. Civic Engagement in Higher Education: Concepts and Practices. San Francisco, CA: Jossey-Bass.

Jaschik, Scott. 2014. “Obama vs. Art History.” Inside Higher Ed, January 31. https://www.insidehighered.com/news/2014/01/31/ obama-becomes-latest-politician-criticize-liberal-arts-discipline. 
Kerrigan, Seanna M, Vicki L. Reitenauer, and Nora Arevalo-Meier. 2015. “Enacting True Partnerships within Community-Based Learning: Faculty and Community Partners Reflect on the Challenges of Engagement." Metropolitan Universities 26 (3): 63-77. http://journals.iupui.edu/index.php/muj/article/view/21106/20511.

Kimball, Roger. 1990. Tenured Radicals: How Politics Has Corrupted Our Higher Education. Chicago, IL: Ivan R. Dee.

King, Rebekka. 2016. "Civic Engagement in the Heart of the City." In Teaching Civic Engagement, Forrest Clingerman and Reid B. Locklin, eds., 74-87. New York, NY: Oxford University Press.

Levine, Peter. 2014. "A Defense of Higher Education and Its Civic Mission.” The Journal of General Education 63 (1): 47-56. https://doi.org/10.5325/igeneeduc.63.1.0047.

Lewis, Dan A. 2014. "Engagement and Citizenship: A New Core for the University." The Journal of General Education 63 (1): 57-63. https://muse.jhu.edu/article/539554/pdf.

Lippmann, Walter. 1932. “The Scholar in a Troubled World.” The Atlantic Monthly. https://sciencepolicy.colorado.edu/students/ envs 5000/lippmann 1932.pdf.

Lovett, Bobby L. 2015. America's Historically Black Colleges and Universities: A Narrative History, 1837-2009. Macon, GA: Mercer University Press.

Luckritz Marquis, Timothy. 2018a. “Meeting Ourselves: A Classroom Exercise on Race, Ethnicity, and Culture.” How Timely The Feet, Feb. 14. https://tluckmarq.wordpress.com/2018/02/14/meeting-ourselves-a-classroom-exercise-on-race-ethnicity-andculture/.

Luckritz Marquis, Timothy. 2018b. “SEBK 842: Ethnicity, Race, and New Testament Interpretation.” Moravian College, Bethleham, PA. Unpublished Syllabus.

Mager, Robert F. 1997. Preparing Instructional Objectives: A Critical Tool in the Development of Effective Instruction (3rd ed.). Atlanta, GA: The Center for Effective Performance.

Matthew, Patricia A. 2016. “What Is Faculty Diversity Worth to a University?” Nov. 23. The Atlantic. https://www.theatlantic.com/ education/archive/2016/11/what-is-faculty-diversity-worth-to-a-university/508334/.

Mitchell, Koritha. 2015. “I'm a Professor. My Colleagues Who Let Their Students Dictate What They Teach Are Cowards.” Vox, June 10. https://www.vox.com/2015/6/10/8753721/college-professor-fear.

Mooney, Linda A., and Bob Edwards. 2001. “Experiential Learning in Sociology: Service Learning and Other Community-Based Learning Initiatives.” Teaching Sociology, 29 (2): 181-194. https://doi.org/10.2307/1318716.

Morton, Mavis. 2009. "Community-Based Learning: Practices, Challenges, and Reflections." Collected Essays on Learning and Teaching 2: 198-202. https://files.eric.ed.gov/fulltext/E)1057069.pdf.

Musil, Caryn McTighe. 2015. “A Step Away from Complacent Knowing’: Reinvigorating Democracy through the Humanities.” Arts \& Humanities in Higher Education 14 (3): 239-59. https://www.aacu.org/sites/default/files/files/CLDE/Arts Humanities Musil.pdf.

Myers, William R., Tina Pippin, Cláudio Carvalhaes, and Neomi De Anda. 2019. “Forum of Paulo Freire’s Pedagogy: Leaning Educationally Into Our Future.” Teaching Theology and Religion 22: 56-72. https://doi.org/10.1111/teth.12472.

Nash, Margart A. 2018. Women's Higher Education in the United States: New Historical Perspectives. New York, NY: Palgrave Macmillan.

News Literacy Project. 2020. Washington, DC: The News Literacy Project. newslit.org. 
Nussbaum, Martha. 2010. Not For Profit: Why Democracy Needs the Humanities. Princeton, NJ: Princeton University Press.

Patterson, Barbara A.B. (Bobbi), Leslie Munoz, Leah Abrahms, and Caroline Bass. 2015. “Transformative Learning: A Case for Using Grounded Theory as an Assessment Analytic." Teaching Theology and Religion 18, no. 4: 303-325.

https://doi.org/10.1111/teth.12301.

Pearson, Thomas. 2016. "Religious Studies, Theology, and Pedagogies of Civic Engagement." In Teaching Civic Engagement, Forrest Clingerman and Reid B. Locklin, eds., 224-44. New York, NY: Oxford University Press.

Perkinson, James W. 2012. “Pedagogy Beyond Piracy: Un-Learning the White Body to Recreate a Body of Learning.” Teaching Theology and Religion 15, no. 4: 323-337. https://doi.org/10.1111/j.1467-9647.2012.00825.X.

Peters, Scott J. 2010. Democracy and Higher Education: Traditions and Stories of civic engagement. East Lansing, MI: Michigan State University Press.

Pippin, Tina. 2016. “Dreams of Democracy.” In Teaching Civic Engagement, Forrest Clingerman and Reid B. Locklin, eds., $245-266$. New York, NY: Oxford University Press.

Posman, Ellen. 2016. "Discourse, Democracy, and the Many Faces of Civic Engagement: Four Guiding Objectives for the University Classroom." In Teaching Civic Engagement, Forrest Clingerman and Reid B. Locklin, eds., 3-22. New York, NY: Oxford University Press.

Posman, Ellen, and Reid B. Locklin. 2016. "Sacred Sites and Staging Grounds: The Four Guiding Objectives of Civic Engagement in the Religion Classroom.” In Teaching Civic Engagement, Forrest Clingerman and Reid B. Locklin, eds., 23-44. New York, NY: Oxford University Press.

Rademacher, Nicholas. 2016. “Religious Diversity, Civic Engagement, and Community-Engaged Pedagogy.” In Teaching Civic Engagement, Forrest Clingerman and Reid B. Locklin, eds., 125-142. New York, NY: Oxford University Press.

Ramye, Steven W. 2006. “Critiquing Borders: Teaching about Religions in a Postcolonial World.” Teaching Theology and Religion 9, no. 4: 211-220. https://doi.org/10.1111/j.1467-9647.2006.00286.x.

Reed-Bouley, Jennifer, and Eric Kyle. 2015. “Challenging Racism and White Privilege in Undergraduate Theology Contexts: Teaching and Learning Strategies for Maximizing the Promise of Community Service-Learning.” Teaching Theology and Religion 18, no. 1: 20-36. https://doi.org/10.1111/teth.12260.

Reyhner, Jon, and Jeanne Eder. 2017. American Indian Education: A History. 2nd Edition. Norma, OK: University of Oklahoma Press.

Runions, Erin. 2012. “With an Eye to Public Engagement.” In Webster et al., "Student Learning Outcomes for Biblical Studies in the Liberal Arts." Teaching Theology and Religion 15, no. 3: 262-283 [264-266]. https://doi.org/10.1111/i.14679647.2012.00807.x.

Saltmarsh, John, and Matthew Hartley. 2011a. “Democratic Engagement." In “To Serve a Larger Purpose”: Engagement for Democracy and the Transformation of Higher Education, 14-26. Philadelphia, PA: Temple University Press.

Saltmarsh, John, and Matthew Hartley. 2011b. “Introduction: “To Serve a Larger Purpose.” In “To Serve a Larger Purpose”: Engagement for Democracy and the Transformation of Higher Education, 1-13. Philadelphia, PA: Temple University Press.

Scott, Mark S.M. 2014. "Reading Together: The Art of Classroom Encounters with Primary Texts." Teaching Theology and Religion 17, no. 1: 80. https://doi.org/10.1111/teth.12163.

Scheid, Anna Floerke, and Elisabeth T. Vasko. 2014. "Teaching Race: Pedagogical Challenges in Predominantly White Undergraduate Theology Classrooms.” Teaching Theology and Religion 17, no. 1: 27-45. https://doi.org/10.1111/teth.12157.

Seemiller, Corey, and Meghan Grace. 2016. Generation Z Goes to College. San Francisco, CA: Jossey-Bass. 
Shanks-Alexander, Elizabeth. 2013. Gender and Timebound Commandments in Judaism. Cambridge, UK: Cambridge University Press.

Smith, Bruce L.R., Jeremy D. Mayer, and A. Lee Fritschler, eds. 2008. Closed Minds? Politics and Ideology in American Universities. Washington, D.C.: Brookings Institution Press.

Social Sciences Feminist Network Research Interest Group. 2017. "The Burden of Invisible Work in Academia: Social Inequalities and Time Use in Five University Departments." Humboldt Journal of Social Relations 1 (39): 228-245. https://digitalcommons. humboldt.edu/cgi/viewcontent.cgi?article=1016\&context=hjsr.

Solomon, Barbara. 1986. In the Company of Educated Women: A History of Women and Higher Education in America. New Haven, CT: Yale University Press.

Sparks, E., and M.J. Waits. 2011. Degrees for What Jobs? Raising Expectations for Universities and Colleges in a Global Economy. Washington, D.C.: National Governors Association.

St. Mary’s University. 2020a. “About St. Mary’s.” https://www.stmarytx.edu/about/.

St. Mary’s University. 2020b. “Community Engagement.” https://www.stmarytx.edu/outreach/civic-engagement/.

Stanford University. 2020. “Stanford’s Mission.” http://exploredegrees.stanford.edu/stanfordsmission/.

Stanford University Haas Center. 2020. “Haas Center for Public Service.” https://haas.stanford.edu/.

Stein, Wayne. 1992. Tribally Controlled Colleges: Making Good Medicine. New York, NY: Peter Lang Publishing.

Stewart, Melissa. 2016. “Teaching for Civic Engagement.” In Teaching Civic Engagement, Forrest Clingerman and Reid B. Locklin, eds., 47-60. New York, NY: Oxford University Press.

Teel, Karen. 2014. "Getting out of the Left Lane: The Possibility of White Antiracist Pedagogy." Teaching Theology and Religion 17, no. 1: 3-26. https://doi.org/10.1111/teth.12156.

Texas A\&M University. 2020. “Texas A\&M University Mission Statement.” https://www.tamu.edu/statements/mission.html.

Upson-Saia, Kristi, and Maria Doerfler. 2020. "Politics and the Pedagogue of Late Antiquity." The Wabash Center Journal on Teaching 1, no. 3: 9-22. https//:doi.org/10.31046/wabashcenter.v1i3.1785.

University of California. 2020. “UC's Mission.” https://ucop.edu/uc-mission/index.html.

University of Wisconsin. 2020. “The Wisconsin Idea.” https://www.wisc.edu/wisconsin-idea/.

Vasko, Elisabeth T. 2017. "Civic Learning and Teaching as a Resource for Sexual Justice: An Undergraduate Religious Studies Course Module.” Teaching Theology and Religion 20, no. 2: 162-170. https://doi.org/10.1111/teth.12383.

Wiersma, Hans. 2016. “Engaging Media and Messages in the Religion Classroom.” In Teaching Civic Engagement, Forrest Clingerman and Reid B. Locklin, eds., 88-108. New York, NY: Oxford University Press.

Wingeier-Rayo, Philip. 2016. “Service and Community-Based Learning: A Pedagogy for Civic Engagement and Critical Thinking.” In Teaching Civic Engagement, Forrest Clingerman and Reid B. Locklin, eds., 109-124. New York, NY: Oxford University Press.

Webster, Jane S., Erin Runions, Eugene V. Gallagher, Davina C. Lopez, Sheila E. McGinn, Todd C. Penner, and David B. Howell. 2012. "Student Learning Outcomes for Biblical Studies in the Liberal Arts." Teaching Theology and Religion 15, no. 3: 262-283. https://doi.org/10.1111/j.1467-9647.2012.00807.x.

Woody, Thomas. 1929. A History of Women's Education in the United States. New York, NY: The Science Press. 
Woolard, Chad. 2017. Engaging Civic Engagement: Framing the Civic Education Movement in Higher Education. Boulder, CO: Lexington Books.

Wright, Almeda. 2019. "Whose Voice Counts? Gender, Power, and Epistemologies in the Seminary Classroom.” Teaching Theology and Religion 22, no. 3: 176-190. https://doi.org/10.1111/teth.12489.

Yale University. 2020. "Traditions and History." https://www.yale.edu/about-yale/traditions-history.

\section{ABOUT THE AUTHORS}

Sara Ronis is Assistant Professor of Theology at St. Mary's University in San Antonio, Texas. She teaches courses on the Hebrew Bible and its reception, focusing on issues of gender and sexuality, migration, and Jewish traditions of biblical interpretation. In her book manuscript, Sara explores how late antique Jews thought about demons as part of larger intercultural conversations in the Sasanian east.

Travis Proctor is Assistant Professor of Religion at Wittenberg University in Springfield, Ohio. He specializes in religions of the ancient Mediterranean, with a focus on histories of Christian cultures in the ancient world (ca. 50-500 CE). His research draws on perspectives from cultural studies, gender studies, and the environmental humanities to demonstrate how the histories of religious cultures have continuing significance for society today. His current research explores early Christian theorizations of nonhuman bodies-particularly those of evil "demons"-and how such conceptualizations impacted early Christian interactions with their cosmic "ecosystems." His other research interests include topics in ancient environmental history, space and material culture, ecocriticism, posthumanism, and ritual studies. 
